\title{
INTERRELATIONSHIPS OF SOME METABOLIC EFFECTS OF TESTOSTERONE PROPIONATE IN NORMAL MALES DURING RESTRICTED SODIUM INTAKE ${ }^{1,2}$
}

\author{
By E. RAYMOND BORUN ${ }^{3}$ AND ERNEST GEIGER WITH THE TECHNICAL ASSISTANCE \\ OF LOTTA DALBERG
}

\author{
(From the Departments of Medicine and Pharmacology, University of Southern California \\ School of Medicine, Los Angeles, Calif.)
}

(Submitted for publication April 5, 1956; accepted June 29, 1956)

Testosterone propionate (T.P.) has been used to stimulate protein anabolism in a variety of clinical conditions (1-5). Metabolic studies have repeatedly demonstrated that the hormone produces nitrogen retention and an increase in body weight in normal subjects as well as in hypogonad individuals (1-6). However, there are discrepancies between the amount of weight gained and the amount of tissue synthesis calculated from the nitrogen retention $(1-4,6)$. Usually the weight gain is greater than the calculated tissue synthesis but occasionally considerable nitrogen retention occurs without a parallel increase in body weight (7). The weight gain in excess of calculated tissue synthesis has been attributed to an accumulation of extracellular fluid secondary to sodium and chloride retention (1-3); in some instances retention of these electrolytes is indeed sufficient to account for the major portion of the weight gain as an isosmotic increment of extracellular fluid (1-3). Such observations suggest that the relationship between the change in body weight and nitrogen retention might be clarified if sodium and chloride retention were rigidly controlled. We therefore studied the metabolic effects of the hormone in normal adult males maintained on restricted sodium and chloride intake.

\section{PROCEDURE}

Subjects and experimental plan: Six well-nourished normal young adult males (five medical students and one

\footnotetext{
1 Supported by a grant from the Los Angeles County Heart Association.

2 Some of the data were previously published in Clin. Res. Proc., 1955, 3, 60.

8 This study was done during the tenure of an Orange County Heart Association research fellowship. Present Address: Department of Medicine, University of California Medical Center at Los Angeles, Los Angeles 24, California.
}

physician) were subjects for this study. Routine medical histories, physical examinations, blood counts, and urinalyses revealed no significant abnormalities. Other data are given in Table I. The subjects continued their normal activities during the study but were requested to avoid physical exertion or environmental situations which might result in sweating or chilling. Despite the fact that the experiments were performed in the winter and spring, sensible perspiration could not be entirely eliminated. The five medical students lived together and underwent the experiments simultaneously; the study of one subject (E.R.) preceded this and differed in some details.

Experiment A consisted of a four-day preliminary adjustment to the special diet, a ten-day control period, and ten days of T.P.4 administration (100 mgm. in oil I.M. daily). Experiment B consisted of a four-day preliminary period, ten days of T.P. administration in the same dosage, and a ten-day recovery period. In three subjects (M. L., S. C., and S. M.) experiment B followed A after a sixweek rest period; in the other subjects experiment $B$ was performed first and was followed by $A$ after the sixweek rest period. In one subject (E. R.) the preliminary periods were of two days duration and the experiments were terminated after twenty days.

In four subjects (E. R., R. B., S. C., and S. M.) the ability to excrete a standard water load was tested at similar intervals during each ten-day period. The water load ( $20 \mathrm{ml}$. per $\mathrm{Kg}$. body weight) was ingested within 10 to 15 minutes and urine specimens were voided every half hour for four hours. The water was ingested about 8:00 A.M. in the fasting state and the subjects remained in bed during the next four hours except while voiding; breakfast and lunch were eaten at the conclusion of the experiment.

Diet: The quantities of food and fluid were self-selected prior to the study from a limited list which provided a low sodium diet (12 to $16 \mathrm{mEq}$.) adequate in all essential constituents. Dietary intake (Table I) remained essentially constant throughout all metabolic periods. Fluid intake was constant except for the additional amounts used in the diuresis experiments and a few other exceptions (Table II ${ }^{5}$ ). The diets of all subjects except

4 Supplied by the Schering Corporation.

- Table II (body weight and metabolic balance data) has been deleted at the suggestion of the editors. Copies of the table are available on request. 
TABLE I

Clinical and dietetic data

\begin{tabular}{|c|c|c|c|c|c|c|c|}
\hline \multirow[b]{2}{*}{ Subject } & \multirow[b]{2}{*}{ Age } & \multirow[b]{2}{*}{$\begin{array}{l}\text { Height } \\
c m .\end{array}$} & \multirow[b]{2}{*}{$\begin{array}{c}\text { Weight } \\
K_{\mathbf{g}} .\end{array}$} & \multicolumn{4}{|c|}{ Daily Dietary Intake } \\
\hline & & & & $\begin{array}{l}\text { Protein } \\
\mathbf{G m} .\end{array}$ & $\begin{array}{c}\text { Carbohydrate* } \\
\text { Gm. }\end{array}$ & $\begin{array}{l}\text { Fat* } \\
\text { Gm. }\end{array}$ & Calories* \\
\hline $\begin{array}{l}\text { F. R. } \\
\text { R. B. } \\
\text { S. C. } \\
\text { S. M. } \\
\text { E. R. } \\
\text { M. L. }\end{array}$ & $\begin{array}{l}26 \\
23 \\
24 \\
23 \\
35 \\
26\end{array}$ & $\begin{array}{l}171 \\
183 \\
180 \\
187 \\
178 \\
192\end{array}$ & $\begin{array}{l}66.50 \\
77.75 \\
70.50 \\
86.05 \\
70.75 \\
81.70\end{array}$ & $\begin{array}{r}112 \\
104 \\
105 \\
121 \\
88 \\
119\end{array}$ & $\begin{array}{l}320 \\
265 \\
296 \\
368 \\
223 \\
362\end{array}$ & $\begin{array}{l}142 \\
112 \\
112 \\
141 \\
101 \\
128\end{array}$ & $\begin{array}{l}3,089 \\
2,554 \\
2,685 \\
3,319 \\
2,209 \\
3,155\end{array}$ \\
\hline
\end{tabular}

* Calculated from food tables (11).

E. R. were high in protein (105 to $125 \mathrm{Gm}$.) and potassium ( 150 to $165 \mathrm{mEq}$.) to provide optimal conditions for protein synthesis. These characteristics were obtained in a palatable and easily prepared diet by using liberal quantities of a fresh low-sodium milk. ${ }^{6}$ One subject (M. L.) added $3 \mathrm{Gm}$. of sodium chloride to his daily diet to provide a comparison between the effects of T.P. during moderate and low sodium intake in the same experimental situation. Single lots of canned and prepared foods were used when feasible. Lean ground round steak was weighed out in individual portions and stored frozen; portions were weighed again after cooking to determine average fluid loss. All other foods were weighed and fluids measured after preparation. Distilled water was used throughout the study.

Observations and collections of specimens: Body weight was measured to the nearest $1 / 8$ th pound every morning after voiding (weights were converted to the nearest $0.050 \mathrm{Kg}$.). Twenty-four hour urine volume and specific gravity were measured; the specimens were acidified with sulfuric acid and toluene was added as a preservative. Stools were weighed daily, homogenized in 4 or 5 day pools, acidified, and stored frozen. Half portions of a complete diet were homogenized daily, acidified, and stored frozen. Fasting blood specimens were drawn after removal of the tourniquet; the portion for electrolyte analysis was immediately placed under oil and the serum promptly removed after clotting had occurred.

Analytical methods: Dry weights of diets, stools, and pooled urine aliquots, were determined by drying 2 to 5 $\mathrm{Gm}$. portions to constant weight in a vacuum dessicator at $75^{\circ} \mathrm{C}$. Diet and stool homogenates and two-day urine aliquots were analyzed for total nitrogen by semi-micro and macro-Kjeldahl methods, sodium and potassium by Perkin-Elmer flame photometer with lithium internal standard, and chloride by the Volhard-Arnold method (8). Diet and stool homogenates were prepared for electrolyte analysis by digestion with nitric acid (9). The chloride concentration of diet and stool digests were below the range of optimum accuracy for the VolhardArnold method. Serum nitrogen, sodium, and potassium, were determined by the same methods, chlorides by the method of Schales and Schales (10), and NPN by nesslerization. Nitrogen and chloride determinations were

6 Supplied by Edgemar Farms, Venice, California. done in duplicate, and urine nitrogen determinations were repeated in duplicate.

Calculations: Fat and carbohydrate content of the diets were calculated from food tables (11); values for the other constituents in Table I were obtained by averaging analytical results from eight aliquots of each diet. $\mathrm{Ni}$ trogen, potassium, sodium and chloride balances were calculated for five-day periods by subtracting the amounts excreted in the urine and stool from the intake. Since the urines of experimental days 5-6 and 15-16 were analyzed as single two-day aliquots, half the total values from these aliquots were arbitrarily assigned to the appropriate five-day period.

Water balance was calculated from the formulas of Newburgh and his associates $(12,13)$ and Lavietes $(14)$ : $\Delta$ Water $=\Delta$ Weight $+\left(\mathrm{S}_{0}-\mathrm{S}_{1}\right)+\mathrm{C}_{1}+\mathrm{F}_{\mathrm{b}}+3.06 \mathrm{~N}_{\mathrm{v}}$ where $S_{1}$ is solids excreted, $S_{1}$ is solids ingested, $C_{t}$ is carbohydrates ingested, $F_{b}$ is fat burned, and $N_{a}$ is urine nitrogen, all in grams. The fat burned was calculated from the formula of Newburgh, Johnston, Lashmet, and Sheldon (13): $F_{b}=\frac{I L-\left(2.18 C_{1}+12.26 N_{u}\right)}{3.93}$, where IL is insensible weight loss and is calculated from the formula: $I L=\left(W_{1}-W_{2}\right)+\left(W_{1}-W_{0}\right)$, where $W_{1}, W_{2}$, $W_{t}$, and $W_{.}$are, respectively, the initial and final body weights and weights of ingesta and excreta. The calculations are subject to errors inherent in the basic assumptions and technique as well as errors due to sensible perspiration and fluctuations of body temperature (14). The water balance data are presented and interpreted with these reservations in mind.

The mean changes in body weight, and the water, nitrogen, potassium, sodium, and chloride balances during the preliminary and control periods were determined in the group of subjects on low sodium intake. Differences between control period data and similar data obtained during the T.P. and recovery periods in the same subject were used to calculate "net" changes (Tables II 5 and III). Differences between the two entire T.P. periods and also between the corresponding halves of each T.P. period were determined by comparing both the means and the individual differences. Similarly, changes that occurred during the first and second half of every period were compared with each other and with the entire control period. Ratios between two different types of data 


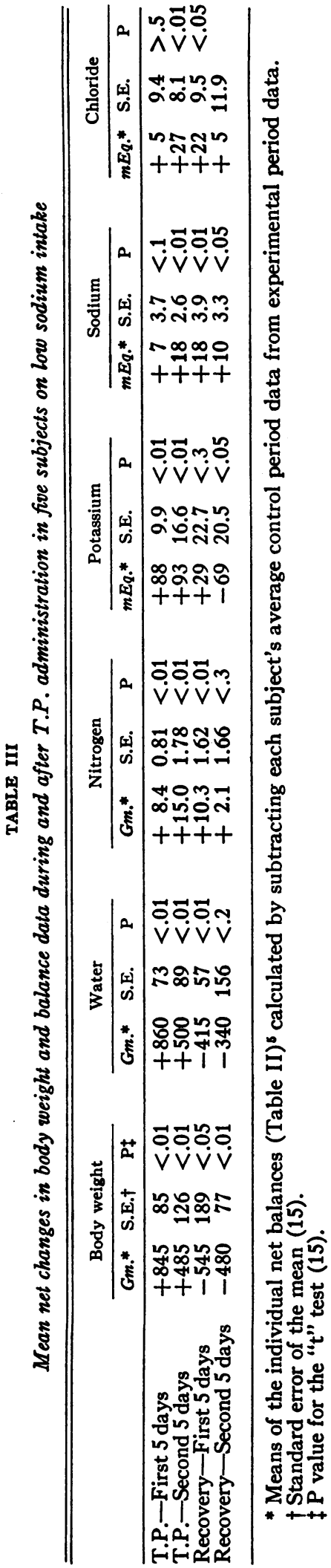

were calculated as the quotients of the mean net changes (Table IV). The Fisher " $t$ " test was applied to the standard errors of the mean changes, differences between means, means of individual differences, and the ratios of the means (15). The degrees of freedom were assumed to be one less than the number of values used in each calculation. Since two sets of T.P. period values were obtained from each subject, this was not a true random sample and therefore the statistics must be used with caution for generalizations beyond the present group of subjects. However, when the two sets of T.P. data from each subject were averaged and the degrees of freedom were assumed to be one less than the number of subjects, the level of significance for mean net changes and means of individual differences between the two halves of the T.P. periods were similar to those obtained from the previous type of calculations. Differences are considered significant with $\mathrm{p}<0.01$ and probably significant with $\mathrm{p}<0.05$.

\section{RESULTS}

\section{Systemic and local reactions}

The control periods were uneventful. There were no complaints about the monotony or palatability of the food even after 24 days on the constant low-sodium diet. Four subjects noted sensations of increased temperature, perspiration unrelated to exertion, nervousness, or tachycardia, during T.P. administration. Two subjects had temperatures of $99.6^{\circ} \mathrm{F}, 100.2^{\circ} \mathrm{F}$ and $100.6^{\circ} \mathrm{F}$ on single occasions coinciding with the sensation of feverishness. Pulse rates were not determined. One subject (S.C.) had an acute, non-febrile pharyngitis and laryngitis during the initial four days of T.P. in Experiment B. All subjects noticed local discomfort and tenderness after the T.P. injections, varying from mild to moderately severe and lasting 24 to 48 hours.

\section{Metabolic Observations in the Five Subjects on Low Sodium Intake}

\section{Body weight and water balance}

Body weight and water were lost during the preliminary periods on the diet $\left(1,160 \pm 139 \mathrm{Gm}^{7}\right.$ and $940 \pm 136 \mathrm{Gm}$. respectively). Variable changes occurred in weight and water balance during the control period; the differences between the changes in weight and water balance should theoretically depend on discrepancies between the in-

\footnotetext{
7 Figures presented in this manner represent the mean \pm standard error.
} 
TABLE IV

Ratios between mean net changes in body weight and balance data during T.P. administration in five subjects on low sodium intake

\begin{tabular}{cccccr}
\hline \hline Period & Gm. Wt./Gm. N & Gm. H.O/Gm. N & Gm. Wt./mEq. K & Gm. H.O/mEq. K & mEq. K/Gm. N \\
\hline T.P.-First 5 days & $101 \pm 10.1^{*}$ & $102 \pm 8.7$ & $9.6 \pm 0.96$ & $9.8 \pm 0.83$ & $10.5 \pm 1.18$ \\
T.P.-Second 5 days & $32 \pm 8.4$ & $33 \pm 5.9$ & $5.2 \pm 1.36$ & $5.4 \pm 0.96$ & $6.2 \pm 1.07$
\end{tabular}

* Quotient of the mean net changes (Table III) \pm standard error (15). These mean net changes are all positive, indicating an increase in body weight, water, nitrogen, and potassium during the T.P. periods.

take and expenditure of calories during that period (12-14).

All five subjects had net weight gain and net water retention during both T.P. periods as compared with the control period; weight gain was greater in Experiment A than Experiment $B$ $(p<0.05)$. The mean net weight gain $(1,280 \pm$ $161 \mathrm{Gm}$.$) and water retention (1,315 \pm 162 \mathrm{Gm}$.) were significant, and the larger portion of both changes occurred during the first five days of T.P. $(p<0.02)$. The mean net water retention/ weight gain ratio during T.P. administration was $1.02 \pm 0.18$.

There was net weight loss $(1,100 \pm 298 \mathrm{Gm}$.) and water loss $(740 \pm 204 \mathrm{Gm}$. $)$ in all five subjects during the recovery period. The net water loss was considerably less than weight loss in two subjects and more than the weight loss in the others.

\section{Nitrogen balance}

During the control period the nitrogen balance was negative in two subjects who lost weight and was positive in the three who gained weight. Net nitrogen retention occurred in all five subjects during both T.P. periods, and was greater in Experiment $A$ than in Experiment $B(p<0.05)$. The mean net nitrogen retention during T.P. periods $(23.1 \pm 2.4 \mathrm{Gm} \text {. })^{8}$ was significant, and the larger portion ( $\mathrm{p}<0.01$ ) occurred during the second five days. The amount of nitrogen which each subject retained during T.P. periods was not related to his control period balance.

The ratios of net weight gain/nitrogen retention and of water retention/nitrogen retention during the first five days of T.P. administration (101 \pm 10 and $102 \pm 8$, respectively) were both signifi-

8 Correction of the mean net nitrogen balance for changes in NPN concentration (16) does not alter this figure significantly. cantly greater than the ratios during the second five days ( $32 \pm 8$ and $33 \pm 6$, respectively).

Net nitrogen retention continued during the recovery period in all five subjects $(11.0 \pm 1.6 \mathrm{Gm}$., $\mathrm{p}<0.05)$; however, the significant retention was limited to the first five days of the period (10.3 \pm $1.6 \mathrm{Gm}$.).

\section{Potassium balance}

The potassium balance was negative in all the control periods (109 $\pm 51 \mathrm{mEq}$.) despite the high dietary intake, and did not correlate with the simultaneous nitrogen balance. Since the control period potassium balance in the subject receiving a sodium chloride supplement was negative also, this could represent an undetected systematic error rather than a secondary effect of sodium restriction (17).

Net potassium retention occurred in all five subjects during the T.P. periods ( $181 \pm 25 \mathrm{mEq}$.). There was no significant difference between the two T.P. periods or between the first and second halves of these periods. The ratios of net weight gain/potassium retention and of water retention/ potassium retention during the first five days of T.P. (9.6 \pm 1.0 and $9.8 \pm 0.8$, respectively) were significantly greater than during the second five days ( $5.2 \pm 1.4$ and $5.4 \pm 1.0$, respectively). The ratio of net potassium retention/nitrogen retention during the first five days of T.P. $(10.5 \pm 1.2)$ was significantly greater than during the second five days $(6.2 \pm 1.1)$.

Changes in potassium balance were not consistent during the first half of the recovery period, but there was significant net loss during the second half (69 $\pm 21 \mathrm{mEq}$.).

\section{Sodium and chloride balance}

Sodium and chloride were lost during the preliminary period on the diet $(165 \pm 38 \mathrm{mEq}$. and 
$188 \pm 21 \mathrm{mEq}$. respectively). The control period sodium balances were slightly positive $(64 \pm 16$ $\mathrm{mEq}$.) but correction for skin loss would reduce these figures considerably (18). Net changes in sodium and chloride balances were not significant during the first five days of the T.P. periods. Very slight but statistically significant net sodium and chloride retention occurred during the second five days of the T.P. periods $(18 \pm 3 \mathrm{mEq}$. and $27 \pm 8 \mathrm{mEq}$. respectively), and continued during the recovery period. $(24 \pm 5 \mathrm{mEq}$. and $27 \pm 20 \mathrm{mEq}$.).

\section{Metabolic Observations in the Subject Receiving} a Sodium Chloride Supplement (M. L.)

Despite the $51 \mathrm{mEq}$. of sodium chloride which this subject added to his food daily, he lost weight and was in negative water, sodium, and chloride

TABLE V

Blood chemistry

\begin{tabular}{|c|c|c|c|c|c|c|c|}
\hline Subject & Exp. & Period & Day & $\underset{m E q_{.} / L}{\mathrm{Na}^{*}}$ & $\underset{m E q . / L .}{C l *}$ & $\underset{m g m . \%}{\mathrm{NPN}}$ & $\begin{array}{l}\text { Protein** } \\
\text { Gm. \% }\end{array}$ \\
\hline \multirow[t]{2}{*}{ F. R. } & B & $\begin{array}{c}\text { T.P. } \\
\text { Recovery }\end{array}$ & $\begin{array}{r}5 \\
15 \\
25\end{array}$ & & $\begin{array}{l}103.0 \\
102.2 \\
101.3\end{array}$ & $\begin{array}{l}36 \\
35 \\
30\end{array}$ & $\begin{array}{l}7.40 \\
6.85 \\
7.09\end{array}$ \\
\hline & $\bar{A}$ & $\begin{array}{c}\text { Preliminary } \\
\text { Control } \\
\text { T.P. }\end{array}$ & $\begin{array}{r}1 \\
5 \\
15 \\
25\end{array}$ & $\begin{array}{l}135.6 \\
131.0 \\
130.4 \\
130.0\end{array}$ & $\begin{array}{l}106.6 \\
101.7 \\
102.1 \\
100.4\end{array}$ & $\begin{array}{l}30 \\
44 \\
36 \\
37\end{array}$ & $\begin{array}{l}6.41 \\
6.97 \\
7.03 \\
6.85\end{array}$ \\
\hline \multirow[t]{2}{*}{ R. B. } & B & $\begin{array}{c}\text { T.P. } \\
\text { Recovery }\end{array}$ & $\begin{array}{r}5 \\
15 \\
25\end{array}$ & & $\begin{array}{l}98.3 \\
96.9 \\
98.7\end{array}$ & $\begin{array}{l}38 \\
36 \\
33\end{array}$ & $\begin{array}{l}8.23 \\
7.26 \\
7.28\end{array}$ \\
\hline & $\bar{A}$ & $\begin{array}{c}\text { Preliminary } \\
\text { Control } \\
\text { T.P. }\end{array}$ & $\begin{array}{r}1 \\
5 \\
15 \\
25\end{array}$ & $\begin{array}{l}136.7 \\
135.8 \\
136.7 \\
135.0\end{array}$ & $\begin{array}{r}103.8 \\
101.3 \\
101.1 \\
97.9\end{array}$ & 38 & $\begin{array}{l}7.27 \\
7.68 \\
7.88 \\
7.36\end{array}$ \\
\hline \multirow[t]{2}{*}{ S. C. } & A & $\begin{array}{l}\text { Control } \\
\text { T.P. }\end{array}$ & $\begin{array}{r}5 \\
15 \\
25\end{array}$ & & $\begin{array}{r}100.9 \\
98.7\end{array}$ & $\begin{array}{l}35 \\
34 \\
28\end{array}$ & $\begin{array}{l}7.11 \\
7.21 \\
7.08\end{array}$ \\
\hline & B & $\begin{array}{c}\text { Preliminary } \\
\text { T.P. } \\
\text { Recovery }\end{array}$ & $\begin{array}{r}1 \\
5 \\
15 \\
25\end{array}$ & $\begin{array}{l}136.8 \\
135.6 \\
134.2 \\
133.7\end{array}$ & $\begin{array}{r}103.4 \\
103.5 \\
99.4 \\
101.0\end{array}$ & $\begin{array}{l}34 \\
40 \\
37 \\
40\end{array}$ & $\begin{array}{l}7.04 \\
7.23 \\
7.05 \\
6.98\end{array}$ \\
\hline \multirow[t]{2}{*}{ S. M. } & $\bar{A}$ & $\begin{array}{c}\text { Control } \\
\text { T.P. }\end{array}$ & $\begin{array}{r}5 \\
15 \\
25\end{array}$ & & $\begin{array}{r}106.4 \\
100.9 \\
98.7\end{array}$ & $\begin{array}{l}37 \\
37 \\
31\end{array}$ & $\begin{array}{l}7.55 \\
7.03 \\
6.99\end{array}$ \\
\hline & B & $\begin{array}{c}\text { Preliminary } \\
\text { T.P. } \\
\text { Recovery }\end{array}$ & $\begin{array}{r}1 \\
5 \\
15 \\
25\end{array}$ & $\begin{array}{l}137.0 \\
136.7 \\
133.7 \\
135.0\end{array}$ & $\begin{array}{r}104.0 \\
99.8 \\
97.9 \\
102.3\end{array}$ & $\begin{array}{l}37 \\
43 \\
33\end{array}$ & $\begin{array}{l}6.84 \\
6.67 \\
6.91 \\
6.77\end{array}$ \\
\hline \multirow[t]{2}{*}{ E. R. } & B & $\begin{array}{c}\text { T.P. } \\
\text { Recovery }\end{array}$ & $\begin{array}{r}3 \\
13 \\
18\end{array}$ & $\begin{array}{l}132.6 \\
133.5 \\
130.4\end{array}$ & & & \\
\hline & $\bar{A}$ & $\begin{array}{c}\text { Control } \\
\text { T.P. }\end{array}$ & $\begin{array}{r}3 \\
13\end{array}$ & $\begin{array}{l}134.7 \\
136.8\end{array}$ & & & \\
\hline \multirow[t]{2}{*}{ M. L. } & A & $\begin{array}{c}\text { Control } \\
\text { T.P. }\end{array}$ & $\begin{array}{r}5 \\
15 \\
25\end{array}$ & & $\begin{array}{l}105.6 \\
100.9 \\
101.7\end{array}$ & $\begin{array}{l}38 \\
38 \\
29\end{array}$ & $\begin{array}{l}7.20 \\
6.98 \\
7.15\end{array}$ \\
\hline & $\bar{B}$ & $\begin{array}{l}\text { Preliminary } \\
\text { T.P. } \\
\text { Recovery }\end{array}$ & $\begin{array}{r}1 \\
5 \\
15 \\
25\end{array}$ & $\begin{array}{l}137.0 \\
133.0 \\
136.1 \\
128.4\end{array}$ & $\begin{array}{l}104.9 \\
102.2 \\
101.1 \\
101.7\end{array}$ & $\begin{array}{l}36 \\
43 \\
42 \\
39\end{array}$ & $\begin{array}{l}6.80 \\
7.25 \\
6.64 \\
7.14\end{array}$ \\
\hline
\end{tabular}

* Concentration in serum. 
balance during both preliminary periods on the diet. His mean net weight gain $(2,030 \mathrm{Gm}$.) and water retention $(2,330 \mathrm{Gm}$.) during the T.P. periods were greater than the changes in the group on low sodium intake; the significant difference occurred during the second five days of these periods. The mean net nitrogen retention (20.8 Gm.) and potassium retention ( $222 \mathrm{mEq}$.) during the T.P. periods were similar to the retention in the low sodium group, while the mean net sodium retention (160 $\mathrm{mEq}$.) and chloride retention (100 $\mathrm{mEq}$.) were significantly greater in this subject. The major retention of nitrogen occurred in the second half of the T.P. periods, as it did in the low sodium group, and both sodium and chloride retention were also greater in the second half of the T.P. periods while potassium retention occurred approximately equally in the two halves.

There was net loss of both weight $(1,550 \mathrm{Gm}$.) and water $(950 \mathrm{Gm}$.) during the recovery period despite the continuation of net nitrogen retention $(19.9 \mathrm{Gm}$.) ; but unlike the results in the low sodium group, the recovery period changes in this subject were accompanied by net loss of both sodium (132 mEq.) and chloride (124 mEq.).

\section{Blood chemistry (Table $V$ )}

The small magnitude of the changes and incompleteness of the blood chemistry data preclude any definite conclusions about the effects of T.P. administration. The subjects on low sodium intake showed slight decreases in plasma protein and chloride concentration during T.P. periods $(0.29 \pm 0.13 \mathrm{Gm}$. per cent and $2.1 \pm 0.4 \mathrm{mEq}$. per L., respectively) but when compared with control period data the net effects were not significant.

\section{Water diuresis experiments}

A total of nineteen water diuresis experiments were performed in four subjects, as described under Procedures. No consistent differences were observed between results in T.P. periods and control or recovery periods in terms of the time course of diuresis, maximal rate of urine flow, or total volume excreted.

\section{DISCUSSION}

In this study the sodium retaining effect of T.P. was controlled in a group of normal adult males by restricting dietary sodium intake; the sodium excretion dropped to such low levels after a few days of diet restriction that the hormone could not cause much further decrease. The experimental design thus minimized one factor that may account for a variable portion of the weight gain during T.P. administration (1-3), and allows one to compare the changes in body weight and water more directly with changes in nitrogen and potassium balance. However, the effects of the dietary regimen itself, which probably include stimulation of aldosterone secretion $(19,20)$, must be differentiated from changes produced by T.P. Comparison of data from the two T.P. periods with that from the control periods may make this differentiation possible and also compensate to some extent for systematic errors in methodology.

The anticipated major adjustments to the low sodium diet occurred during the preliminary periods (17) ; T.P. administration was then started on the fifth day of the dietary regimen in one experiment and on the fifteenth day in the other experiment so that delayed effects of the diet (17) might be revealed as differences between the two T.P. periods in each subject. The only significant differences observed between the two T.P. periods were the more marked weight gain and nitrogen retention in the experiment where T.P. was started early. Although these differences may be related to the duration of sodium restriction, the fact that they were also present in data from the subject receiving a sodium chloride supplement suggests that they could be secondary to other factors.

T.P. administration consistently produced a weight gain which was somewhat greater than the amount calculated on the basis of the nitrogen retention, assuming a ratio of $32 \mathrm{Gm}$. of weight per Gm. of nitrogen (21-26) (Table IV and Figure 1). Our water balance calculations indicate that the weight gain was essentially due to fluid retention. The subjects on low sodium intake showed an increase in body weight and water out of proportion to the relatively small amount of nitrogen and insignificant amounts of sodium and chloride retained during the first five days of T.P. administration. During the second five days of T.P. administration the increments of body weight and water were related to the nitrogen retention 


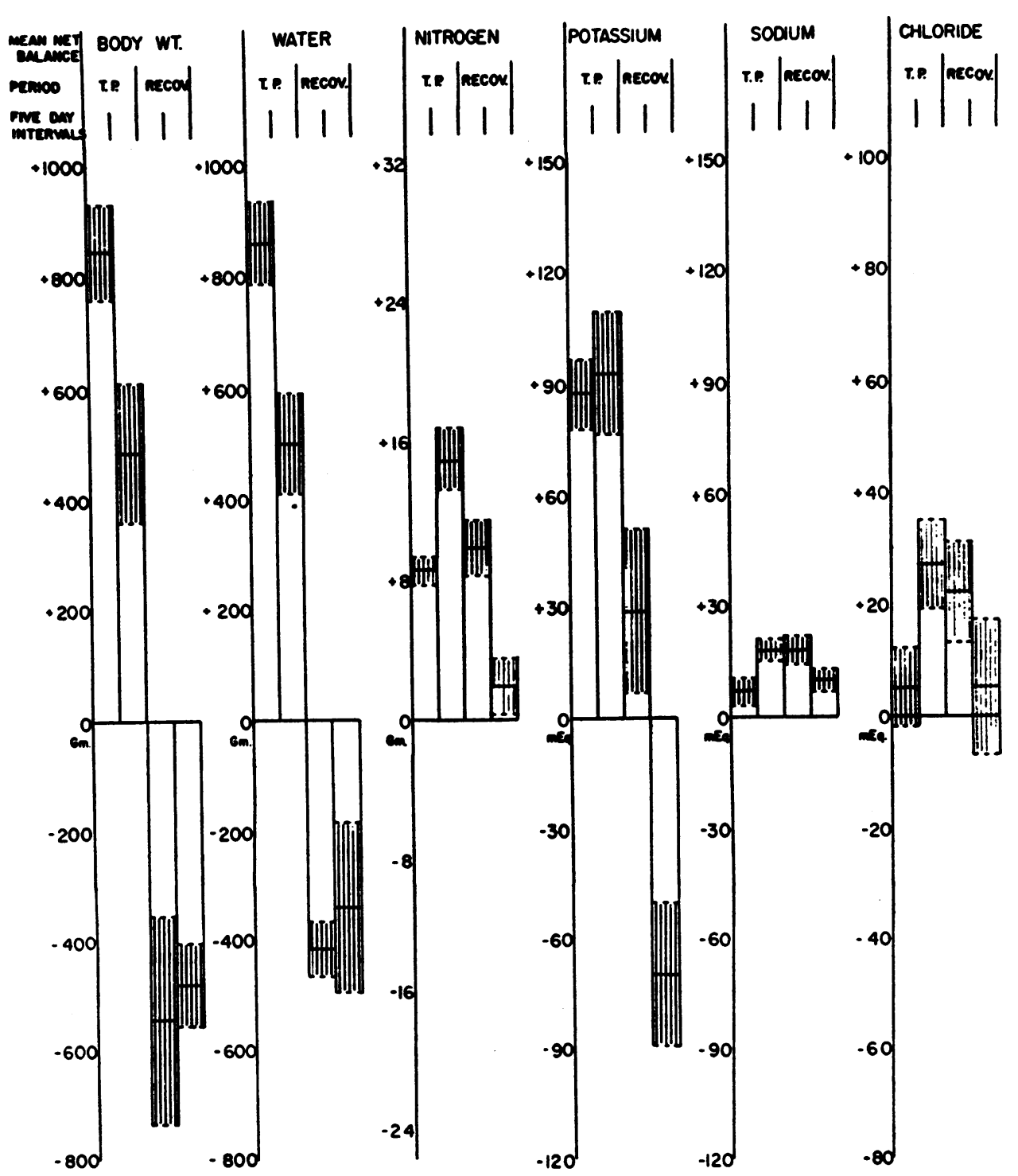

Fig. 1. Mean Net Changes in Body Weight and Balance Data During and After T.P. Administration in Five Subjects on Low Sodium Intake

The shaded areas represent the standard error of each mean. The scales for nitrogen and body weight are related according to the ratio in adult tissue, potassium and water according to the ratio in intracellular fluid, and sodium, chloride and water according to their ratios in extracellular fluid.

by ratios resembling those of normal adult tissue. These subjects lost weight and water during the first five days after T. P. was withdrawn despite the fact that nitrogen retention continued during this period along with slight sodium and chloride retention. Since similar disproportions between body weight and nitrogen balance follow T.P. administration and withdrawal during both normal $(1-4,6)$ and restricted sodium intake, these effects are probably not dependent on the level of sodium intake or sodium retention.

The ratio of water to potassium retained during the first five days of T.P. administration was greater than that normally found in intracellular fluid (24-27), but the ratio approximated that of intracellular fluid by the end of the ten-day period. The ratio of potassium to nitrogen retained during T.P. administration was greater than the 
ratio normally present in adult tissue (23-27); this was particularly noticeable during the initial five days of hormone administration. Since a high ratio of potassium to nitrogen retention has been noted previously during the initial period of T.P. administration $(4,6,28)$, this effect does not depend on the dietary restrictions of the present study.

Comparisons between the relative changes in water, potassium, and nitrogen balances in the subjects on low sodium intake during the two halves of the T.P. periods and recovery period (Table IV and Figure 1) suggest that the administration of T.P. predominately affects the water balance first, potassium balance second, and nitrogen balance third, while withdrawal of the hormone reverses the effects in the same sequence. These relationships may be obscured when changes in sodium and chloride balances are of such magnitude that they can account for significant shifts in extracellular fluid volume (subject M. L.).

We do not know whether T.P. has a primary effect on water or potassium balance, or whether the changes are secondary to other metabolic effects. While it is conceivable that the hormone might cause water retention by a primary antidiuretic action, our water diuresis experiments failed to demonstrate this.

Rudolph and Samuels observed that parallel increases in oxidative metabolism and intracellutar water content occur in rat seminal vesicle tissue within 10 to 20 hours after T.P. administration (29). Unfortunately their data do not include potassium determinations. They attributed the initial increase in intracellular water to an accumulation of osmotically active particles accompanying the change in oxidative metabolism. This explanation could not be applied to the present study without modification because total oxygen consumption in man is usually not increased during the first few days of T.P. administration $(2,30)$.

Relatively high ratios of water to nitrogen and of potassium to nitrogen occur in rapidly growing tissues such as the human fetus $(31,32)$, regenerating rat liver (33-35), , $^{\circ}$ certain neoplasms (35-37). It is possible that the high ratios of water to nitrogen and of potassium to ni-

9 Two studies describe separately a decrease in nitrogen (34) and an increase in potassium (35) per unit dry weight of regenerating rat liver. trogen retained during the first few days of T.P. administration are a reflection of specific metabolic changes which precede or accompany the initial phase of rapid growth. In the present study the experimental design and high dose of hormone apparently tended to isolate and accentuate these effects. Further investigation of these inter-relationships may provide information about the mechanisms by which testosterone affects the balance between anabolic and catabolic processes.

\section{SUMMARY}

1. Metabolic balance data were obtained in five normal adult male subjects on low sodium intake and one subject on moderate sodium intake during 10-day control, T.P., and recovery periods.

2. All subjects showed net weight gain and retention of water, nitrogen, and potassium during T.P. administration.

3. Net weight gain and water retention were greater during the first five days of hormone administration and were out of proportion to the relatively small amount of nitrogen retention. This occurred in the group on low sodium intake despite the absence of net sodium retention during this interval. During the second five days of hormone administration the weight gain and water retention were approximately proportional to the nitrogen retention in this group.

4. Net potassium retention during T.P. administration in the group on low sodium intake was almost sufficient to produce an isosmotic intracellular fluid from the calculated net volume of water retained. The ratio of potassium to nitrogen retained during T.P. administration was considerably higher than that found in normal adult tissue; this ratio was highest during the initial five days of hormone administration.

5. All subjects lost weight and water during the first five days after T.P. was withdrawn despite the fact that the net nitrogen balance was still positive, and the net sodium and chloride balances were also slightly positive in the group on low sodium intake.

6. The results suggest that in the absence of significant sodium and chloride retention T.P. affects the water balance first, potassium balance second, and nitrogen balance third, while withdrawal of the hormone reverses the effects in the same sequence. 


\section{ACKNOWLEDGMENTS}

The authors wish to express their appreciation to Drs. Paul Starr, Robert R. Commons, and Frederick Moore for their interest and encouragement.

\section{REFERENCES}

1. Kenyon, A. T., Sandiford, I., Bryan, A. H., Knowlton, K., and Koch, F. C., The effect of testosterone propionate on nitrogen, electrolyte, water and energy metabolism in eunuchoidism. Endocrinology, 1938, 23, 135.

2. Kenyon, A. T., Knowlton, K., Sandiford, I., Koch, F. C., and Lotwin, G., A comparative study of the metabolic effects of testosterone propionate in normal men and women and in eunuchoidism. Endocrinology, 1940, 26, 26.

3. Reifenstein, E. C., Jr., and Albright, F., The metabolic effects of steroid hormones in osteoporosis. J. Clin. Invest., 1947, 26, 24.

4. Talbot, N. B., Butler, A. M., and MacLachlan, E. A., The effect of testosterone and allied compounds on the mineral, nitrogen, and carbohydrate metabolism of a girl with Addison's disease. J. Clin. Invest., 1943, 22, 583.

5. Forsyth, B. T., The effect of testosterone propionate at various protein and caloric intakes in malnutrition after trauma. J. Lab. \& Clin. Med., 1954, 43, 732.

6. Aronoff, A., Graham, J. E., and McIntosh, H. W., A comparison of the metabolic effects of three preparations of testosterone. Canad. M. A. J., 1954, 71, 340.

7. Borun, E. R., Geiger, E., and Reisinger, E., Changes in body weight due to testosterone propionate during restricted sodium intake. Clin. Res. Proc., 1954, $2,87$.

8. Hawk, P. B., Oser, B. L., and Summerson, W. H., Practical Physiological Chemistry. 12th ed., New York, The Blakiston Co., 1951, pp. 893-894.

9. Wallace, W. M., Holliday, M., Cushman, M., and Elkinton, J. R., The application of the internal standard flame photometer to the analysis of biologic material. J. Lab. \& Clin. Med., 1951, 37, 621.

10. Schales, O., and Schales, S. S., A simple and accurate method for the determination of chloride in biological fluids. J. Biol. Chem., 1941, 140, 879.

11. McLester, J. S., and Darby, W. J., Nutrition and Diet in Health and Disease. 6th ed., Philadelphia, W. B. Saunders Co., 1952, Appendix, Table 144. Composition of foods, pp. 630-663.

12. Newburgh, L. H., Johnston, M. W., and FalconLesses, M., Measurement of total water exchange. J. Clin. Invest., 1929-30, 8, 161.

13. Newburgh, L. H., Johnston, M. W., Lashmet, F. H., and Sheldon, J. M., Further experiences with the measurement of heat production from insensible loss of weight. J. Nutrition, 1937, 13, 203.

14. Lavietes, P. H., The metabolic measurement of the water exchange. J. Clin. Invest., 1935, 14, 57.

15. Bernstein, L., and Weatherall, M., Statistics for Medical and Other Biological Students. Baltimore, Williams and Wilkins Co., 1952.

16. Danowski, T. S., Greenman, L. Mateer, F. M., Parsons, W. B., Weigand, F. A., Mermelstein, H., and Peters, J. H., Carboxylic cation exchange resin effects in dogs. J. Clin. Invest., 1951, 30, 984.

17. Renwick, R., Robson, J. S., and Stewart, C. P., Observations upon the withdrawal of sodium chloride from the diet in hypertensive and normotensive individuals. J. Clin. Invest., 1955, 34, 1037.

18. Arn, K. D., and Reimer, A., Minimal sodium losses through the skin. J. Clin. Invest., 1950, 29, 1342.

19. Luetscher, J. A., Jr., and Johnson, B. B., Observations on the sodium-retaining corticoid (aldosterone) in the urine of children and adults in relation to sodium balance and edema. J. Clin. Invest., 1954, 33, 1441.

20. Mulrow, P. J., Lieberman, A. H., Johnson, B. B., and Luetscher, J. A., Jr., Potassium to sodium ratio as an index of aldosterone output. J. Clin. Invest., 1956, 35, 726.

21. Pace, N., and Rathbun, E. N., Studies on body composition. III. The body water and chemically combined nitrogen content in relation to fat content. J. Biol. Chem., 1945, 158, 685.

22. Forbes, R. M., Cooper, A. R., and Mitchell, H. H., The composition of the adult human body as determined by chemical analysis. J. Biol. Chem., 1953, 203, 359.

23. Widdowson, E. M., McCance, R. A., and Spray, C. M., The chemical composition of the human body. Clin. Sc., 1951, 10, 113.

24. Harrison, H. E., Darrow, D. C., and Yannet, H., The total electrolyte content of animals and its probable relation to the distribution of body water. J. Biol. Chem., 1936, 113, 515.

25. Mokotoff, R., Ross, G., and Leiter, L., The electrolyte content of skeletal muscle in congestive heart failure; a comparison of results with inulin and chloride as reference standards for extracellular water. J. Clin. Invest., 1952, 31, 291.

26. Talso, P. J., Spafford, N., and Blaw, M., The metabolism of water and electrolytes in congestive heart failure. I. The electrolyte and water content of normal human skeletal muscle. J. Lab. \& Clin. Med., 1953, 41, 281.

27. Ikkos, D., Ljunggren, H., Luft, R., and Sjögren, B., Content and distribution of potassium and chloride in adults. Metabolism, 1955, 4, 231.

28. Kenyon, A. T., in Conference on Metabolic Aspects of Convalescence, Transactions of the Seventeenth Meeting, March 1948, Edward C. Reifenstein, Jr., Ed., New York, Josiah Macy, Jr. Foundation, 1948, p. 51. 
29. Rudolph, G. G., and Samuels, L. T., Early effects of testosterone propionate on the seminal vesicles of castrate rats. Endocrinology, 1949, 44, 190.

30. Sandiford, I., Knowlton, K., and Kenyon, A. T., Basal heat production in hypogonadism in men and its increase by protracted treatment with testosterone propionate. J. Clin. Endocrinol. \& Metab., 1941, 1, 931.

31. Iob, V., and Swanson, W. W., Mineral growth of the human fetus. Am. J. Dis. Child., 1934, 47, 302.

32. Widdowson, E. M., and Spray, C. M., Chemical development in utero. Arch. Dis. Childhood, 1951, 26, 205.

33. Tsuboi, K. K., Yokoyama, H. O., Stowell, R. E., and Wilson, M. E., The chemical composition of re- generating mouse liver. Arch. Biochem. \& Biophys., 1954, 48, 275.

34. Szego, C. M., and Roberts, S., The influence of ovariectomy on the chemical composition of regenerating rat liver. J. Biol. Chem., 1949, 178, 827.

35. DeLong, R. P., Coman, D. R., and Zeidman, I., The significance of low calcium and high potassium content in neoplastic tissue. Cancer, 1950, 3, 718.

36. Waterhouse, C., Terepka, A. R., and Sherman, C. D., Jr., The gross electrolyte composition of certain human malignant tissues. Cancer Research, 1955, 15, 544.

37. Cowdry, E. V., Cancer Cells. Philadelphia, W. B., Saunders Co., 1955, pp. 162-164. 